\title{
Do Firms Change Dividend Policy After Certified or Revoked Shariah- Compliant Status? A Study of Dividend Payout Decisions on Firms in Bursa Malaysia
}

\author{
Rabuan Mantine* ${ }^{* 1}$ and Mohamad Jais ${ }^{2}$ \\ ${ }^{1}$ School of Business and Management, University College of Technology Sarawak, Sibu, \\ Sarawak, Malaysia \\ ${ }^{2}$ Faculty of Economics and Business, Universiti Malaysia Sarawak \\ Corresponding author: rabuanm1@gmail.com
}

\begin{abstract}
Based on the profit sharing concept of Islamic investment, payment of annual dividend is a method of wealth distribution for profits earned by firms. However dividend payout is not compulsory in conventional investment. Among the reasons to hold back dividend payment is for investment purposes which is necessary for both wealth maintenance and growth. Of course, if the investment rate is very high, the present shareholders or investors are deprived of wealth distribution for the benefit of future investors which is against the spirit of profit and losssharing of a partnership in Islam. The question is, would firms change their dividend policy to cater for tacit requirement of divident payment by Islamic investment once certified shariahcompliant status and reverses the policy when shariah-compliant status revoked? Hence, this study, investigates the impacts of the shariah-compliant status of firms in Bursa Malaysia on their dividend payout behavior by analysing their pre- and post-shariah-compliant years data. The results showed that the shariah-compliant status of firms has positive impacts on firms' dividend payout decisions. The revocation of the status, startlingly, does not necessarily overturn the long-held dividend policies of the firms. Instead, the firms maintain consistent dividend policy, perhaps in an effort not to portray negative overtone related to the annulment of the shariah-compliant status to the stockholders and the market.
\end{abstract}

Keywords: Islamic Investors, Islamic Investment, Shariah-Compliant Index, Dividend Decision

\section{Introduction}

The recent global phenomenon arising from the participation of Islamic investors in the modern investment vehicles such as mutual funds and stocks generates interest among researchers on the performance of the new type of screens of indexes which are shariah-compliant.

Islamic investors are investors that are subscribed to Islamic religious values and thus only invest in the types of investments that are shariah-compliant while the Islamic indices or screens are created to attract the Islamic investors who are globally present and currently increasing in number, as well as in capital value ${ }^{1}$.

As Islamic investment is considered new, some compare this new shariah-compliant indices or screens as the same category as ethically or socially responsible investment (SRI).

\footnotetext{
${ }^{1}$ The industry's total worth, according to key industry stakeholder organizations, across its three main sectors (banking, capital markets, and TAKFUL), was estimated to be USD 2.05 trillion in 2017, marking an 8.3\% growth in assets in USD terms, and reversing the preceding two years of assets' growth stagnation (2017: USD 1.89 trillion vs. 2016: USD 1.88 trillion)(Research and Market, 2019, March 21).
} 
SRI investments are restricted to companies which are not involved in, for instance, the tobacco or weapon industry (Derigs \& Marzban, 2008). Other similarities could have been derived from few principles that are coincidentally universally upheld such as avoiding pornography, gambling, liquor or aversion to high levels of debt. However, for an Islamic investor a number of Islamic rules and laws need to be adhered to. These rules and laws are called shariah and stem from three sources (in the following order): Quran, Hadith, and Ijtihad ${ }^{2}$. As such, according to DeLorenzo (2000), Islamic funds and index providers need to hire experienced shariah scholars to interpret the different shariah sources and to specify a set of checkable shariah guidelines, or screens, to be used to distinguish between the set of halal (shariahcompliant) assets and haram (not admissible) assets. Fortunately, in Malaysia, the shariah governance is under the purview of the Shariah Advisory Council (SAC) the regulatory arm of the Securities Commission of Malaysia (Shariah Advisory Council, 2006).

\section{What Are The Motivations of Islamic Investors?}

In Islam, providentially, the virtues of investment philosophy are in fact, embedded in the very prohibitions under the shariah law i.e., the prohibition of usury (riba), gambling or speculation (maisir) and ambiguity (gharar) (Naughton \& Naughton, 2000).

Under the shariah law, basically, Islam acknowledges the need for investment as long as no forbidden elements such as riba, gharar and maisir are involved in the process and also agreeable to the distribution of wealth through dividend payment which in turn enables the Islamic investors to perform their religious obligation called $z a k a h^{3}$ where their wealth are purified by contributing certain percentage of his income to the needy or more accurately the asnaf.

According to the shariah, riba technically refers to "premium" that must be paid by the borrower to the lender along with the principal amount as a condition for the loan or for the extension in the duration of loan (Iqbal \& Mirakhor, 2007). Today, Islamic scholars recognize and prohibit two types of riba. The first is riba al-qurud, or interest on loans. The second is riba al-buyu, or interest in trade. For riba al-qurud, no amount over and above the loan may be given or received by the borrower and lender. Riba al-jahiliyya falls into this category. This prohibition is not only limited to giving additional money; gifts, goods, and services are also included. Riba al-buyu, interest in trade, is further divided into categories. The first is riba al$n a s a$, the interest in forward transactions. If two parties engage in a forward transaction for the delivery of same type of commodity, neither side can defer delivery of the commodity. The second type is referred to as riba al-fadl, or the interest in inequality; it occurs when two parties exchange the same commodity but in different quantities. It is hard to conceive of such transactions that could lead to either riba al-nasa or riba al-fadl occurring in the present day. They can arise quite easily in barter, however. The prohibitions thus discourage barter and encourage cash transactions, which are more efficient (Hardie \& Rabooy, 1991).

The concept of gharar, on the other hand, has been broadly defined by the scholars in two ways. First, gharar implies uncertainty. Second, it implies deceit. In English, gharar can be translated as "risk" or "uncertainty." Islamic jurists know that all financial contracts and transactions entail a certain degree of risk and uncertainty that is unavoidable. Jurists seek to determine whether the risk present in a contract is major or excessive gharar, which would

\footnotetext{
${ }^{2}$ Ijtihad is the Islamic legal term meaning "independent reasoning," as opposed to taqlid (imitation).

${ }^{3}$ Zakah is muslim tithe which is one of the five pillars of Islam besides profession of faith (or shahadah), prayer, fasting and pilgrimage.
} 
invalidate a contract, or minor gharar, which is tolerated. It is important to keep in mind that risk and uncertainty are not haram in and of themselves. Instead, it is the sale of gharar (bay al-gharar in Arabic) that has been expressly forbidden by Prophet Muhammad (pbuh). Another important point is that unbundled risk is also forbidden (El-Gamal, 2000). Generally, gharar is considered to be present when there is incomplete information and/or fraud, as well as uncertainty about the intrinsic nature of the objects in question in a contract (Vogel \& Hayes, 2006). Vogel and Hayes (2006) further explain that there are four instances of transactions that involve unacceptable risk to some extent, all of which are expressly prohibited in various hadiths which are; pure speculation, uncertain outcome, unknowable future benefit and inexactitude

Besides purification of income through zakah, another unique characteristic of the concept of investment in Islam is the purification of the income received through distributed income especially dividend. When included in the portfolio, income from companies which are tainted by an avoidable non-halal activity is purified through a cleansing mechanism (Elgari, 2000). This situation may arise due the timing for the disposal of securities which have been classified as shariah non-compliant. In this regard, the SAC Malaysia advises investors who invest based on shariah principles to dispose of any shariah non-compliant securities which they presently hold, within a month of knowing the status of the securities. Any gain made in the form of capital gain or dividend received during or after the disposal of the securities has to be channeled to charitable bodies or Baitulmal. The investor has a right to retain only the original investment cost (Shariah Advisory Council, 2006). In the case of mutual funds, this purification process is done either by the fund manager before any distribution of income, or by reporting the necessary financial ratios for investors to purify their earnings on their own. This choice is summed up in the "deduct or inform" dilemma. In the first case (deduct), the manager distributes to the investor a "net" (purified) profit. The second option, instead, is more practical: the fund manager informs the investor and advises the part to be purified. In this case, the manager can also indicate to the Muslim investor the part that is subject to zakah, a religious form of charity that all wealthy people must pay on personal wealth every lunar year (Ahmed, 2002). Under a return and market appeal point of view, if no deduction is made from the net asset value of the portfolio, the fund appears more profitable and can also be sold to non-Islamic investors. Such non-Islamic investors would conversely be penalized by the "deduct" option (Forte \& Miglietta, 2007).

Another key aspect of Islamic investment is the emphasis on profit sharing basis (Mansor, 2006;Warde, 2000) as a mode of investment which allows investors that provides capital to enjoy the return in the form of profit which are distributed through dividends while the persons running the business (mudarib) will also get their share in the form of wages.

The spiritual motivations for Islamic investors to participate in investments could be sourced from the Quranic verse below which exhorts the Muslims to seek the bounty or wealth which goes to show that earning a halal living in itself is a fulfillment of religious obligation.

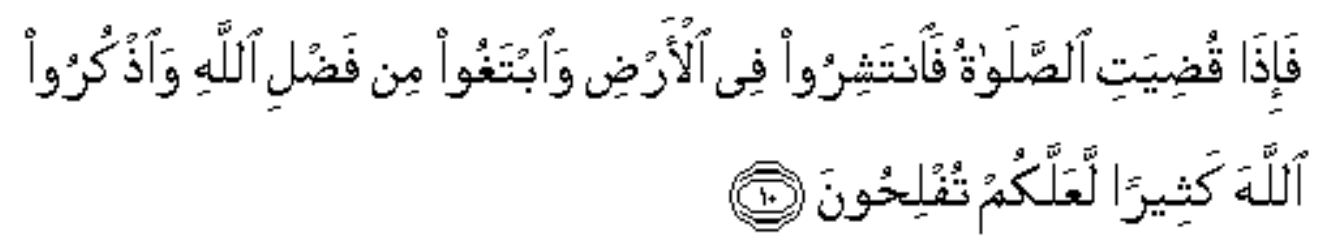


"And when the Prayer is finished, then may ye disperse through the land, and seek of the Bounty of Allah and celebrate the Praises of Allah often (and without stint): that ye may prosper."

While essential obligation such as zakah is one of the five pillars of Islam, then the payment of dividend enables the Islamic investors to fulfill this obligation. However, in the conventional investments, dividend payment is not compulsory. Among the reasons to hold back dividend payment is for investment purposes which is necessary for both wealth maintenance and growth. Of course, if the investment rate is very high, the present shareholders or investors are deprived of wealth distribution for the benefit of future investors which is against the spirit of profit and loss-sharing of a partnership in Islam.

\section{Problem Statement and Hypothesis Development}

Despite the 'complexities' on the motivations of the Islamic investors as mentioned in the preceding paragraphs, nevertheless the shariah-compliant index was launched in Bursa Malaysia (formally known as Kuala Lumpur Stock Exchange) in 1999 partly spurred by the turmoil in the conventional Asian financial markets in 1997 as well as in search for alternative investment direction. The applications of firms to be included in shariah-compliant index would be processed by SAC using the shariah checklists or standards. Firms would be certified shariah-compliant upon passing the fulfilment of the standards. The firms could later be delisted from the shariah-compliant index either on voluntary basis or for failing to maintain the required shariah standards.

Focusing on the preference of Islamic investors on dividend payout as a mean of wealth distribution based on the profit-sharing concept the question arise on whether the shariahcompliant certification would influence firms in their dividend payout decisions.

Thus, using data of firms in Bursa Malaysia covering the period of 1999 to 2010, this study would, therefore, seeks to address the question on the firms' behavior with regard to their dividend payout decisions based on the assumption that the firms are fully aware of the Islamic investment preference on annual dividends. The hypothesis is developed as per below;

Hypothesis: Firms' dividend payout decisions are influenced by the shariah-compliant status

The rest of this article is organized as follows: Section 2 surveys literatures on the preference and influence of different types of investors on dividend payout decisions supported by the relevant dividend theories and followed by the dividend payout decisions of the shariahcompliant firms. Section 3 covers the data description and the data selection procedure followed by the testing methodology. Section 4 presents a discussion of the results, and followed by conclusion in Section 5.

\section{Literature Review}

There are many theories on dividend payout policies and decisions. Basically the theories attempt to explain the basis of dividend payout decisions and also the forces which may have some influence on dividend payout decisions. Due to vast literatures on dividend theories, this article focuses only on dividend theories on the investors' influence or preference for dividend payout and also the shariah-compliant influence on the dividend payout decisions. 


\section{Type of Investors and Dividend Preference}

Below (Table 1) are summary of theories based on the characteristic of investors and their dividend preferences;

Table 1 Types of Investors and Dividend Behavior

\begin{tabular}{lll}
\hline Types of Investors & Dividend Behaviour & Relevant Theories \\
\hline Prudent investors & $\begin{array}{l}\text { Investors who prefer dividend over capital gain for fear } \\
\text { of future risk }\end{array}$ & Bird-in-hand theory \\
\hline Dividend investors & $\begin{array}{l}\text { Investors who use dividend in their investment portfolio } \\
\text { as a steady source of income }\end{array}$ & $\begin{array}{l}\text { Clientele theory \& } \\
\text { Dividend smoothing } \\
\text { theory }\end{array}$ \\
\hline 'Blackout' investors & $\begin{array}{l}\text { Investors who read dividend as a signal of the 'actual' } \\
\text { performance of the firms as they are 'blackout' from the } \\
\text { inside information. }\end{array}$ & Signaling theory \\
\hline Growth investors & $\begin{array}{l}\text { Long term investors' who prefer capital gain by means } \\
\text { of growth stocks/firms over mature firms }\end{array}$ & Life cycle theory \\
\hline Governing investors & $\begin{array}{l}\text { Principal investors who control spending spree by } \\
\text { managers on the free cashflow by way of requiring firms } \\
\text { to pay dividend over unnecessary investments }\end{array}$ & Free cashflow theory \\
\hline
\end{tabular}

Source: Authors

\section{Prudent Investors}

Theory on investors' preference of dividend payments over capital gains due to the uncertainty of the future cashflow is called bird-in-hand theory. The essence of the bird-in-the-hand theory of dividend policy is that shareholders are risk-averse and prefer to receive dividend payments rather than future capital gains. According to Lintner (1962), this dividend policy is in line with the firms' perspective, as higher dividend payout ratio will consequently reduce the required rate of return and increase the firms' value.

\section{Dividend Investors}

Dividend investors are investors who use dividend in their investment portfolio as a steady source of income. Thus, firms that pay dividends are unlikely to reduce the amount of the dividend, because their clientele (institutions) are precisely the kind of investors that will punish them for it. Thus, they keep dividends relatively smooth (Allen, Bernardo, \& Welch, 2000; Kumar, 1988). Institutional investors such as government-link mutual funds ${ }^{4}$ and also employee provident fund ${ }^{5}$ are mostly dependent on annual dividends as a source of income in

\footnotetext{
${ }^{4}$ Permodalan Nasional Berhad or PNB is the largest mutual fund in Malaysia with total investment of RM198.9 billon which translates into $10 \%$ of the total market capitalization of the Bursa Malaysia of RM1,906.8 billion as at 31 Dec 2017 (source: PNB Annual Report Highlights at http://www.pnb.com.my/pdf/ DOSSIER/2018/ [DOSSIER -8pp] \%20PNB\%20AR2017.pdf)

${ }^{5}$ Kumpulan Wang Simpanan Pekerja or KWSP had declared a dividend rate of 6.90 per cent for Simpanan Konvensional, with a payout amounting to RM44.15 billion; and 6.40 per cent for Simpanan Shariah, with a payout amounting to RM3.98 billion. In total, the payout for 2017 amounted to RM48.13 billion, which represented an increase of 29.80 per cent from 2016. KWSP is the fourth biggest employee provident fund in South East Asia with asset size stood at RM814 billion as at 31 Dec 2018 (source: Annual Report 2017 at
} 
order to keep the attractiveness of their funds to the contributors and investors with promises of annual dividend payouts which they never failed to deliver since their inceptions.

\section{Growth Investors}

Growth investors are more interested on the capital gain than dividend. Thus, their focus is on growth stocks rather than matured stocks. Under the life-cycle theory of dividend by Mueller (1972) that investment opportunities decrease with the increase of life cycle stage. Less reinvestment opportunities at mature stage means the firms could generate more cash and able to distribute their excess cashflows in a form of dividend payouts. The recent interest in the life cycle theory of dividends may perhaps be traced to Fama and French's (2001) study of the dividend payment behavior of publicly traded U.S. firms. They investigate the patterns and determinants of payout policy over the 1926-1999 period. Their results point to life cycle factors playing a major role in the decision to pay cash dividends. In particular, their findings show that dividend-paying firms are large and highly profitable. These firms have retained earnings that are sufficient to cover their capital investments. On the other hand, firms that have never paid dividends are small and not as profitable as dividend-paying firms. These firms have many investment opportunities that require external financing because their capital spending is far greater than their earnings. Thus, dividend-paying firms have the characteristics of mature firms, while firms that have never paid dividends have the characteristics of young, fastgrowing firms. Here, growth investors are more interested in young and fast-growing firms.

\section{'Blackout' Investors}

These type of investors perceive any decision on the dividend as signal for the firms' future performance (Allen et al. 2000). The argument of signaling theory is that investors are 'blackout' from the information on the actual firms' performance as compared to the managers and thus have to rely on the changes in the level of dividend payout as a signal of the firms' future performance. Under this theory, the managers are assumed not eager to send the wrong signals to market. It is argued that the firms which anticipate increases in their net earnings would spread the information to the outsiders, whereas the firms which expect reductions in the cashflow would be unlikely to spread such information to the shareholders. The signaling theory however, focuses on the influence of the dividend payout decisions on the investors' investment behavior rather than the influence of the investors on the dividend payout decisions.

\section{Governing Investors}

Governing investors are normally principal investors who have majority control of the firms. These type of investors are more concerned on the governance of the firms by way of requiring firms to distribute profits by way of paying dividend over unnecessary investments at times where free cashflow are available for reinvestments. Free cashflow is the cashflow available after fulfilling all the requirement of the business. The free cashflow hypothesis (Jensen, 1986) implies that the governing investors 'force' the dividends paid out to stockholders in order to prevent managers from building unnecessary empires in their own narrow interests. Entrenched managers have the tendency to invest free cashflow in size-increasing but non profitable projects aligned to self-interest (Kadioglu \& Yilmaz, 2017). The clearer implication of the free

http://www.kwsp.gov.my/-/epf-releases-annual-report-2017) \& The Star at https://www.thestar.com.my/ business/business-news/2014/05/27/epf-asset-size-swells-total-hits-rm597bil-boosted-by-strong-stock-marketperformance/ 
cashflow hypothesis is that the overinvestment problem is likely to be more pronounced in stable, cash-rich companies in mature industries without many growth opportunities (Lang \& Litzenberger, 1989). Thus, governing investors would prefer to see an increase in dividend that would reduce the free cashflow available to the managers.

\section{Shariah-compliant Firms and Dividend Payout Decisions}

Studies on the shariah-compliant investment and dividend payout decisions focus on how the profit and loss sharing principle are employed while maintaining stable dividend payouts. In the study on the Islamic Interest-Free banking (IIFBs) Hassan (2003) observes the maintenance of stable dividend in the IIFBs leads to assets concentration in short and medium investments rather than long term investments as they tend to invest in investments that have more certainty about its return. As compared to conventional banking transactions in IIFBs are regulated by Islamic legal principles which prohibit interest. Any predetermined return in financial transactions is prohibited, regardless of the use of the loan. IIFBs developed alternative interestfree financing techniques. Those techniques have been based on two principles: the profit and loss sharing (PLS) and markup (MUP) principles. The PLS principle is the cornerstone of contractual transactions. Thus, in this study, IIBs found to be balancing the need for annual dividend payouts while juggling in the choice between short-medium term and long term investments to avoid risks and uncertainties.

In another study, Guizani (2017) finds the dividend payments of shariah-compliant firms respond more strongly to free cashflow than do the dividend payments of shariah noncompliant firms. In his study, he examined how shariah-compliance mitigates the agency cost of free cashflow by using dividend policy in the context of firms listed on Gulf Co-operation Council (GCC) country stock exchanges. Appling a panel regression to a data set composed of 1242 observations from 207 companies during the period 2009-2014 the results of the study show that shariah-compliant firms not only have higher payout ratios but also have higher likelihood to pay dividends which implies shariah-compliant firms are more stringent in preventing managers from misusing the resources in ways that may not maximize shareholder wealth.

The earlier study on the performance of shariah-compliant firms in Bursa Malaysia was conducted by Rahman and Wajdi (2006). They tried to examine whether shariah-compliant firms pay higher dividend than shariah non-compliant firms during end of 2004. The result of the study shows that shariah-compliant firms pay higher dividend to their shareholders than shariah non-compliant firms. Further, this study found that shariah-compliant firms facing less agency cost than shariah non-compliant firms. Further, they also attempted to provide empirical evidence on whether shariah and shariah non-compliant firms have different level of agency cost. The study uses Cost of sales, Sales and general administration expense, Annual sales, and Dividend per share as study variables.

\section{Data Descriptions}

\section{Shariah-compliant Status Changes}

Unlike previous researches on shariah-compliant firms and dividend payout decisions by Hassan (2003), Rahman and Wajdi (2006) and also Guizani (2017), this study is not about shariah-compliant firms verses shariah non-compliant firms. The purpose of this study is to analyse the impact of the certification or revocation of the shariah-compliant status on the firms' dividend payout decisions. Therefore we do not select all firms but rather focusing on 
firms which experience changes in shariah-compliant status either accorded a shariahcompliant status while previously shariah non-compliant (henceforth Sample-A) or revoked shariah-compliant status after previously shariah-compliant (henceforth Sample-B) (see Table 2). In that manner, we can compare the performance of firms in two periods i.e. during the shariah non-compliant years against shariah-compliant years. Thus, to fulfill this requirement at least one year of data are available before and after the shariah-compliant for each firm. It should be noted that Sample-B comprises firms relatively more mature than Sample-A by virtue of their early listing in the stock market.

The number of firms attaining shariah-compliant status for the period of 1999-2010 are 693 firms excluding those listed during launching of Kuala Lumpur Shariah Index (KLSI) in 1999 whereas those losing Shariah-compliance status are 186. However, the number selected for the samples slightly reduced to 299 and 30 respectively upon closer inspection and selection based on the study criteria set above.

Table 2 Sample-A and Sample-B: Changes in Shariah Compliance Status (Year1999 to 2010)

\begin{tabular}{lll}
\hline Sample Type & Status Changes & $\boldsymbol{N}$ \\
\hline Sample-A & From shariah non-compliant shariah-compliant to shariah-compliant & 299 \\
\hline Sample-B & From shariah-compliant to shariah non-compliant & 30 \\
\hline
\end{tabular}

Source: Authors

\section{Market Recovery and Market Stability Periods}

Analysis also made on the performance of the firms on both Sample-A and Sample-B during the market recovery period (henceforth Period-P1) and market stability period (henceforth Period-P2) (see Figure 1). Period-P1 is the period between 1999 until 2004 which is the recovery period from the Asian financial market turmoil in 1997. Period-P2 is the period between 2005 until 2010 during which market recovers and sustains its performance. The segregation of the two market conditions is proxied by the performance of Kuala Lumpur Composite Index (KLCI) which is shown in Figure 1.

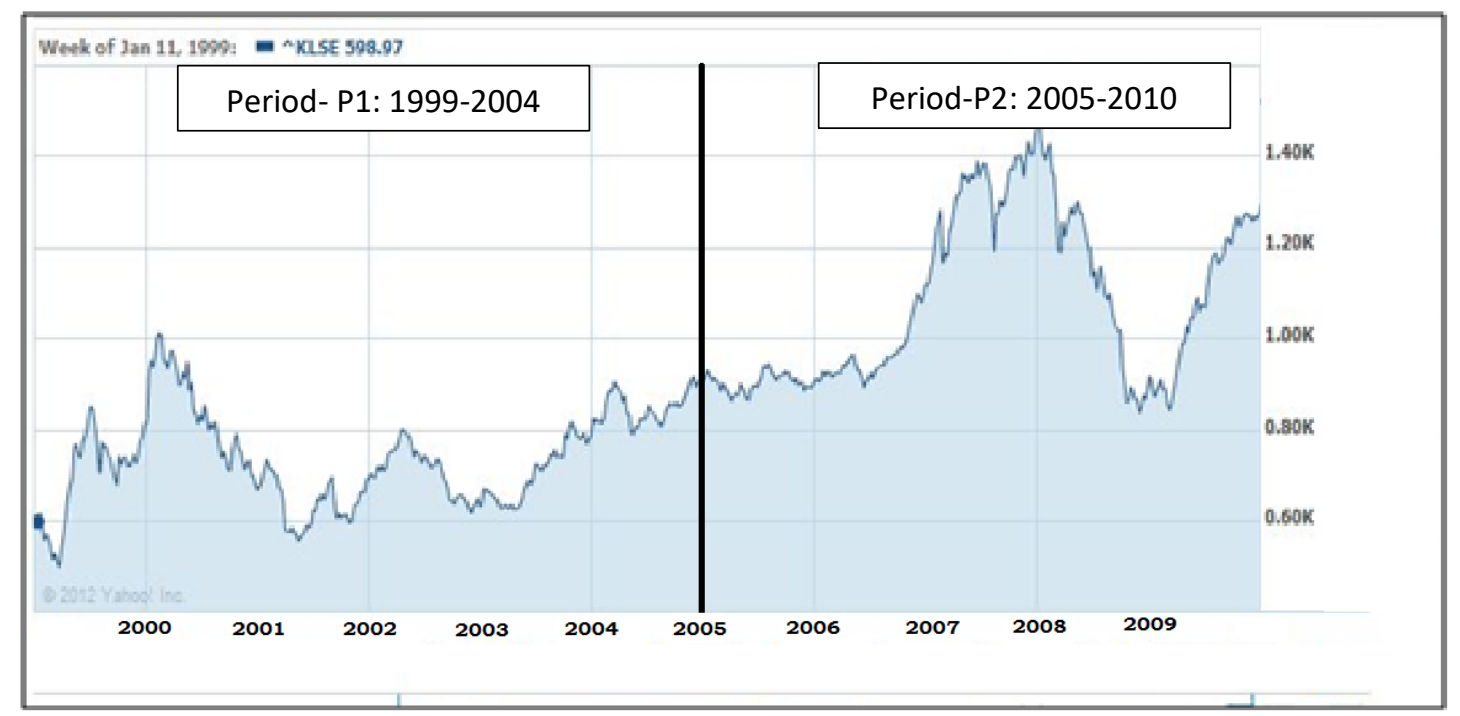




\section{Figure 1 KLCI market performance for the period 1999-2010}

Source: finance.yahoo.com

\section{Variables}

Four variables selected to represent various wealth characteristics and performance of a firm and used in the various tests in this study are shown below (Table 3):

Table 3 Firms Wealth and Performance Variables

\begin{tabular}{|c|c|c|}
\hline $\begin{array}{l}\text { Variable } \\
\text { Abbreviations }\end{array}$ & Name and Formula & Measurement on firm's performance \\
\hline ROA & $\begin{array}{l}\text { Return on Assets } \\
=\frac{\text { Net Income }}{\text { Total Assets }}\end{array}$ & $\begin{array}{l}\text { A measurement on how efficiently a company } \\
\text { can manage its assets to produce profits during a } \\
\text { period. Following Barber and Lyon (1996) }\end{array}$ \\
\hline LMktCap & $\begin{array}{l}\text { Market Capitalization } \\
=\text { Market Price X } \\
\text { No. of Shares Outstanding }\end{array}$ & $\begin{array}{l}\text { A measurement on the size of a firm. Following } \\
\text { Bichara (2008) }\end{array}$ \\
\hline DebtAsset & $\begin{array}{l}\text { Debt-to-asset ratio } \\
=\frac{\text { Total Debt }}{\text { Total Assets }}\end{array}$ & $\begin{array}{l}\text { A measurement of firm's financial leverage. } \\
\text { Similar to Wald (1999) }\end{array}$ \\
\hline DivSize & $\begin{array}{l}\text { Dividend Size } \\
=\underline{\text { Dividend Amount }} \\
\text { Common Shares }\end{array}$ & $\begin{array}{l}\text { A measurement on the size of dividend payouts } \\
\text { over common shares }\end{array}$ \\
\hline
\end{tabular}

Source: Authors

Other two variables to be used representing shariah-compliant status and dividend payout decisions are as below (Table 4):

Table 4 Shariah-compliant and Dividend Variables

\begin{tabular}{|l|l|l|}
\hline Variable & \multicolumn{1}{|c|}{ Name of Variable } & Assigned values \\
\hline ShariahComp & $\begin{array}{l}\text { =Shariah compliance status } \\
\text { of a firm }\end{array}$ & $\begin{array}{l}\text { A dummy binary variable that equals one (1) is assigned to } \\
\text { the firm if the firm is a shariah-compliant firm and zero (0) } \\
\text { if otherwise; }\end{array}$ \\
\hline DivDec & $\begin{array}{l}\text { = Dividend payout decision } \\
\text { of a firm. }\end{array}$ & $\begin{array}{l}\text { A dummy binary variable that equals to one (1) is assigned if } \\
\text { the firm is a Dividend Payer and zero (0) if the firm is } \\
\text { Dividend Non-payer. }\end{array}$ \\
\hline
\end{tabular}

Source: Authors

\section{Methodology}

Using all the variables above, there are three tests conducted in this study namely McNemar's Chi-square test, logistic regression and paired t-test.

\section{McNemar's Chi-square Test}

Prior to Logistic regression, the binary dependent variable which is the dividend payout decisions (DivDec) are tested using McNemar's Chi-square test which is the basis of the proposed test by McNemar (1947) to examine the marginal probabilities for each outcomes which are dividend payers or dividend non-payers prior or after the firms were being accorded shariah-compliant status or after being stripped of shariah-compliant status. McNemar's Chisquare test is a form of paired $t$-test or the within-subjects ANOVA. The McNemar test is used 
to measure the subject twice, which in this instance, the firms' decision to pay or not to pay dividend before and after being accorded the shariah-compliant status or before and after being stripped of shariah-compliant status.

The test is applied to a $2 \times 2$ contingency table, which tabulates the outcomes of two tests on a sample of $n$ subjects, as follows (Table 5);

Table 5 McNemar's Chi-square Test Table

\begin{tabular}{|l|c|c|c|}
\hline & Test 2 positive & Test 2 negative & Row total \\
\hline Test 1 positive & $a$ & $b$ & $a+b$ \\
\hline Test 1 negative & $c$ & $d$ & $c+d$ \\
\hline Column total & $a+c$ & $b+d$ & $n$ \\
\hline
\end{tabular}

Source: Authors

The null hypothesis of marginal homogeneity states that the two marginal probabilities, $p$ for each outcome, $a, b, c, d$ are the same, i.e. $p_{a}+p_{b}=p_{a}+p_{c}$ and $p_{c}+p_{d}=p_{b}+p_{d}$. Thus the null and alternative hypotheses are;

$$
\begin{aligned}
& H_{o}: p_{b}=p_{c} \\
& H_{l}: p_{b} \neq p_{c}
\end{aligned}
$$

Here $p_{a}$, etc., denote the theoretical probability of occurrences in cells with the corresponding label.

McNemar's statistic is represented by;

$$
X^{2}=\frac{(b-c)^{2}}{(b+c)^{2}}
$$

\section{Binary Logistic Regression (Logit Model)}

This test is conducted to support or verify the result of McNemar's Chi-square test above. Binary Logistic regression is a type of regression analysis where the dependent variable is a dummy variable: coded 0 (dividend non-payment decision) or 1 (dividend payment decision). Therefore the Logistic distribution constrains the estimated probabilities to lie between 0 and 1 denoting dividend non-payment and dividend payment decisions respectively. Thus, the estimated probability is;

$$
p=1 /[1+\exp (-\alpha-\beta \mathrm{X})]
$$

Taking the natural log of (13) the "logit" model solves these dividend payment decisions probabilities as:

$$
\ln [p /(1-p)]=Y=\alpha+\beta \mathrm{X}+\mathrm{e}
$$

Where;

$$
\begin{array}{ll}
P & =\text { the probability that the event } \mathrm{Y} \text { occurs, } \mathrm{p}(\mathrm{Y}=1) ; \\
p /(1-p) & = \\
& \text { the "odds ratio" of dividend payment over dividend non-payment } \\
& \text { decisions; }
\end{array}
$$




$$
\ln [p /(1-p)] \quad=\quad \text { the } \log \text { odds ratio, or "logit" }
$$

Substituting dependent variable $Y$ and independent variable $X$ in (14) the logit equation becomes;

$$
\ln [p /(1-p)]=\text { DevDec }=\alpha+\beta_{1} \text { ShariahComp }+\beta_{2} \text { LMktCap }+\beta_{3} \text { DebtAsset }+\beta_{4} R O A+\varepsilon_{i}
$$

Where;

(i) Dependent variable;

DivDec $=$ Dividend payout decision of a firm.

(ii) Independent variables;

$$
\begin{array}{ll}
= & \text { the intercept (the value of dependent variables when the value of all } \\
& \text { independent variables are zero); } \\
= & \text { are the vectors or slopes associated with the independent variables. } \\
\beta_{1} \text { to } \beta_{4} & \text { Shariah compliance status of a firm. } \\
\text { ShariahComp } & \text { Natural log of Market capitalization; } \\
\text { LMktCap } & =\text { Debt-to-asset ratio; } \\
\text { DebtAsset } & \text { Return on assets; and } \\
\text { ROA } & \text { the error terms associated with unobservable factors that may affect } \\
\varepsilon_{i} & \text { the dependent variable. }
\end{array}
$$

\section{Paired t-test}

The paired sample $t$-test, sometimes called the dependent sample $t$-test, is a statistical procedure used to determine whether the mean difference between two sets of observations is zero. In a paired sample t-test, each subject or entity is measured twice, resulting in pairs of observations. In this study the pairs of observations are the means of dividend size (DivSize) in the pre ( -3 to -1 years) and post $(+1$ to +3$)$ event year or the year the shariah-compliant status change for each firm.

\section{Results}

Table 6 Summary of General Conclusions on Impacts of Shariah-Compliant Status

\begin{tabular}{|l|l|}
\hline Analysis & Impacts of Shariah-compliant Status for All Samples \\
\hline McNemar's Chi-square test & $\uparrow$ Increase in Dividend Payers from Non-Payers \\
\hline Logistic Regression & $\uparrow$ Positive correlation to dividend payout decisions \\
\hline Paired t-test & $\uparrow$ Increase in dividend size \\
\hline
\end{tabular}

Source: Authors

The general conclusion on the empirical results of the three tests confirm the hypothesis that firms' dividend payout decisions are influenced by the shariah-compliant status. All tests employed show that shariah-compliant status has favorable impacts on firms for both SampleA and Sample-B which are summarized in Table 6. The detail analysis on the three results are presented in succeeding paragraphs. 


\section{The results of McNemar's Chi-Square test}

Table 7 McNemar's Chi-Square Test - Dividend payout decisions Before Shariahcompliant VS Dividend payout decisions After Shariah-compliant Cross-TabulationFor Sample-A

\begin{tabular}{|c|c|c|c|c|}
\hline \multicolumn{5}{|c|}{$\underline{\text { Sample-A }}$} \\
\hline & & \multicolumn{3}{|c|}{ After Shariah-compliant } \\
\hline \multirow{5}{*}{ 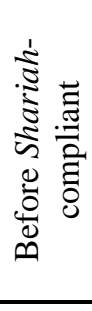 } & & \multicolumn{3}{|c|}{ Overall Period (1999-2010) } \\
\hline & & Dividend Non-Payer & Dividend Payer & Total \\
\hline & $\begin{array}{l}\text { Dividend } \\
\text { Non-Payer }\end{array}$ & $\begin{array}{c}94 \\
64 \%\end{array}$ & $\begin{array}{c}53 \\
36 \%\end{array}$ & $\begin{array}{c}147 \\
100 \%\end{array}$ \\
\hline & $\begin{array}{c}\text { Dividend } \\
\text { Payer }\end{array}$ & $\begin{array}{c}22 \\
14 \% \\
\end{array}$ & $\begin{array}{r}130 \\
86 \% \\
\end{array}$ & $\begin{array}{c}152 \\
100 \% \\
\end{array}$ \\
\hline & Total & 116 & 183 & 299 \\
\hline & $\begin{array}{l}\text { cNemar Test } \\
\text { exact -sided) } \\
P \text {-value }\end{array}$ & \multicolumn{2}{|c|}{$0.000 * * *$} & \\
\hline & Inference & \multicolumn{2}{|c|}{ Reject $H_{0}$} & \\
\hline \multicolumn{5}{|c|}{$\begin{array}{l}\text { Note:. Payer and Non-payer refer to firms that pay and do not pay dividend respectively. "Before Shariah- } \\
\text { compliant refers" to the financial years in which a firm is still not yet in the Kuala Lumpur Shariah index } \\
\text { (KLSI) and "After Shariah-compliant years", on the other hand, refer to the financial years in which a firm } \\
\text { is in the Kuala Lumpur Shariah index (KLSI) after being accorded the Shariah-compliant status. ***, **, * } \\
\text { represent significant level at } 1 \%, 5 \% \text { and } 10 \% \text { respectively }\end{array}$} \\
\hline
\end{tabular}

Source: Authors

Table 8 McNemar's Chi-Square Test - Dividend payout decisions Before Shariah Noncompliant VS Dividend payout decisions After Shariah Non-compliant CrossTabulation- For Sample-B

\begin{tabular}{|c|c|c|c|c|}
\hline \multicolumn{5}{|c|}{$\underline{\text { Sample-B}}$} \\
\hline & & \multicolumn{3}{|c|}{ After Shariah Non-compliant } \\
\hline \multirow{5}{*}{ 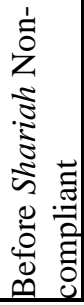 } & & \multicolumn{3}{|c|}{ Overall Period (1999-2010) } \\
\hline & & Dividend Non-Payer & Dividend Payer & Total \\
\hline & $\begin{array}{l}\text { Dividend } \\
\text { Non-Payer }\end{array}$ & $\begin{array}{c}17 \\
89 \% \\
\end{array}$ & $\begin{array}{c}2 \\
11 \% \\
\end{array}$ & $\begin{array}{c}19 \\
100 \%\end{array}$ \\
\hline & $\begin{array}{l}\text { Dividend } \\
\text { Payer } \\
\end{array}$ & $\begin{array}{c}0 \\
0 \% \\
\end{array}$ & $\begin{array}{c}11 \\
100 \% \\
\end{array}$ & $\begin{array}{c}11 \\
100 \% \\
\end{array}$ \\
\hline & Total & 17 & 13 & 30 \\
\hline \multicolumn{2}{|c|}{$\begin{array}{l}\text { McNemar Test } \\
\text { (exact } 2 \text {-sided) } \\
P \text {-value }\end{array}$} & \multicolumn{3}{|l|}{0.500} \\
\hline \multicolumn{2}{|c|}{ Inference } & \multicolumn{3}{|l|}{ Accept $H_{0}$} \\
\hline \multicolumn{5}{|c|}{$\begin{array}{l}\text { Note: Payer and Non-payer refer to a firm that pays and doesn't pay dividend respectively. Unlike } \\
\text { Sample-A, Sample-B started as shariah-compliant firms before being stripped of the shariah-compliant } \\
\text { certification and become shariah non-compliant firms. Thus "Before Shariah Non-compliant refers" to } \\
\text { the financial years in which a firm is still the Kuala Lumpur Shariah Index (KLSI) and "After Shariah }\end{array}$} \\
\hline
\end{tabular}


Non-compliant years", on the other hand, refer to the financial years in which a firm is no longer in the

Kuala Lumpur Shariah Index (KLSI) after the annulment of its' Shariah-compliant status. ***, **,* represent significant level at $1 \%, 5 \%$ and $10 \%$ respectively.

Source: Authors

The results of McNemar's chi-square test of Sample-A (refer Table 7) show the favorable impacts of shariah-compliant certification on the dividend payout decisions. It is found about $36 \%(N=53)$ dividend non-payers become dividend payers after shariah-compliant certification compared to only $24 \%(N=22)$ of dividend payers become dividend non-payers.

Surprisingly, the revocation of shariah-compliant status in Sample-B (refer Table 8) does not change the dividend payout decisions behavior of the firms as the results show that $100 \%(N=11)$ of the firms still maintain the dividend payout policy as previously adopted during shariah-compliant years.

\section{The Results of Logit Model Regression Analysis}

Table 9 Dividend payout decisions among firms in Sample-A and Sample-B during different period: Logit regressions analysis (Newton-Raphson model)

\begin{tabular}{|c|c|c|c|c|c|c|}
\hline \multirow{4}{*}{ Variables } & \multicolumn{6}{|c|}{ Dependent Variable: Dividend payout decisions (DivDec) } \\
\hline & \multicolumn{3}{|c|}{$\underline{\text { Sample-A }}$} & \multicolumn{3}{|c|}{$\underline{\text { Sample-B }}$} \\
\hline & $\begin{array}{l}\text { Overall } \\
\text { Period }\end{array}$ & $\begin{array}{c}\text { Period-P1 } \\
(1999- \\
2004) \\
\end{array}$ & $\begin{array}{c}\text { Period-P2 } \\
(2005- \\
2010) \\
\end{array}$ & $\begin{array}{l}\text { Overall } \\
\text { Period }\end{array}$ & $\begin{array}{c}\text { Period-P1 } \\
(1999- \\
2004) \\
\end{array}$ & $\begin{array}{c}\text { Period-P2 } \\
(2005- \\
2010)\end{array}$ \\
\hline & $\begin{array}{c}\text { coef } \\
(p \text {-value })\end{array}$ & $\begin{array}{c}\text { coef } \\
(p \text {-value })\end{array}$ & $\begin{array}{c}\text { coef } \\
(p \text {-value })\end{array}$ & $\begin{array}{c}\text { coef } \\
(p \text {-value })\end{array}$ & $\begin{array}{c}\text { coef } \\
(p \text {-value })\end{array}$ & $\begin{array}{c}\text { coef } \\
(p \text {-value })\end{array}$ \\
\hline \multirow[t]{2}{*}{$\alpha$} & $-2.8396^{* * *}$ & $-1.6904^{*}$ & $-5.0610^{* * *}$ & $-17.0971^{* *}$ & 43.9589 & $-43.5925^{*}$ \\
\hline & $(0.0003)$ & $(0.0970)$ & $(0.0001)$ & $(0.0205)$ & $(0.2904)$ & $(0.0767)$ \\
\hline \multirow[t]{2}{*}{ ShariahComp } & $0.7556^{* * *}$ & $0.7650^{* * *}$ & $0.7137^{* *}$ & -0.2399 & -6.0079 & 1.4933 \\
\hline & $(0.0000)$ & $(0.0024)$ & $(0.0123)$ & $(0.7628)$ & $(0.2174)$ & $(0.3251)$ \\
\hline \multirow[t]{2}{*}{ LMktCap } & $0.4417^{* * *}$ & 0.1955 & $0.9383^{* * *}$ & $3.0887^{* *}$ & -7.5577 & $7.7948^{*}$ \\
\hline & $(0.0035)$ & $(0.3080)$ & $(0.0007)$ & $(0.0190)$ & $(0.2853)$ & $(0.0743)$ \\
\hline \multirow[t]{2}{*}{ DebtAsset } & -0.2736 & -0.3175 & -1.0624 & $-10.2074^{* * *}$ & -20.9599 & -19.0716 \\
\hline & $(0.3559)$ & $(0.2889)$ & $(0.2359)$ & $(0.0071)$ & $(0.4128)$ & $(0.1167)$ \\
\hline \multirow[t]{2}{*}{$R O A$} & $8.8223^{* * * *}$ & $12.3788^{* * * *}$ & $6.2223^{* * *}$ & $40.3018^{* * *}$ & 34.5884 & 59.1662 \\
\hline & $(0.0000)$ & $(0.0000)$ & $(0.0001)$ & $(0.0095)$ & $(0.4276)$ & $(0.1379)$ \\
\hline$N$ & 600 & 332 & 268 & 60 & 26 & 34 \\
\hline$R^{2}$ & 0.1069 & 0.1197 & 0.1241 & 0.5090 & 0.7768 & 0.6662 \\
\hline
\end{tabular}

Source: Authors

The results of the Logistic regression analysis are shown in Table 9. Based on the results Sample-A shows significant positive correlations of shariah-compliant (ShariahComp) on the firms' dividend payout decisions (DivDec), with coefficients ranging from 0.7137 to 0.7650 at $1 \%$ to $5 \%$ significant levels, in all market conditions indicating the positive impacts of the shariah-compliant certification of the firms on the dividend payout decisions. Surprisingly, the revocation or cancellation of shariah-compliant status (ShariahComp) on the firms in Sample- 
B show no significant impact on the dividend payout decisions (DivDec) in all market conditions. The results of Logit regression on other variables showed that dividend payout decisions (DivDec) are also correlated to Market Capitalization (LMktCap), especially market stability period (Period-P2) in both samples with positive coefficients of 0.4417 and 3.0887 for overall periods. The relatively more mature firms (Sample-B), with limited growth prospect, are negatively influenced by leverage (DebtAsset) ratio in their dividend payout decisions without any bias towards specific market condition with negative coefficient at -10.204 significant at $1 \%$ level. The influence of DebtAsset ratio to dividend payout decisions (DivDec) in new firms (Sample-A) is simply absent. The positive significant correlations between return on assets (ROA) with dividend payout decisions (DivDec) are found in Sample-A during all market conditions with $1 \%$ significant level but only in the Overall period in Sample-B with $1 \%$ significant level. The results suggest the different market conditions influence the degree of association of firm's profitability with dividend payout decisions in Sample-A but are irrelevant in Sample-B.

\section{The Results of Paired t-test}

Table 10 Paired $t$-test for Dividend Size (DivSize) For Sample-A and Sample-B

\begin{tabular}{|c|c|c|c|c|c|}
\hline \multirow{4}{*}{$\underline{\text { Sample-A }(N=300)}$} & \multicolumn{2}{|c|}{ Means for Dividend Size } & \multicolumn{3}{|c|}{ Test for equality of means } \\
\hline & \multicolumn{2}{|c|}{$\begin{array}{l}\text { Shariah-compliant Years } \\
\text { Minus (-) } \\
\text { Non Shariah-compliant Years }\end{array}$} & \multicolumn{3}{|c|}{ paired $t$-test } \\
\hline & Mean & Std. Dev. & t-value & $\begin{array}{l}\text { 2-tailed } \\
\text { (p-value) }\end{array}$ & Inference \\
\hline & & & & & \\
\hline Overall Period & 0.5411 & 2.6216 & $3.5688 * * *$ & 0.0004 & Reject Ho \\
\hline $\begin{array}{l}\text { Period-P1 (1999- } \\
2004)\end{array}$ & 0.4975 & 2.5038 & $2.5521 * *$ & 0.0116 & Reject Ho \\
\hline $\begin{array}{l}\text { Period-P2 (2005- } \\
2010)\end{array}$ & 0.5948 & 2.7683 & $2.4871 * *$ & 0.0141 & Reject Ho \\
\hline$\underline{\text { Sample-B }(N=30)}$ & & & & & \\
\hline Overall Period & -0.1767 & 1.8612 & -0.5199 & 0.6071 & Accept Ho \\
\hline $\begin{array}{l}\text { Period-P1 (1999- } \\
2004)\end{array}$ & -0.1769 & 2.3672 & -0.2695 & 0.7921 & Accept Ho \\
\hline $\begin{array}{l}\text { Period-P2 (2005- } \\
2010)\end{array}$ & -0.1765 & 1.4407 & -0.5050 & 0.6204 & Accept Ho \\
\hline $\begin{array}{l}\text { Note: } \\
\text { Sample-A: status chan } \\
\text { Sample-B: status chan } \\
\text { Period-P1: Market rec } \\
\text { Period-P2: Market stab } \\
* * * * * * \text { denote signi }\end{array}$ & $\begin{array}{l}\text { es from shar } \\
\text { es from shar } \\
\text { yery period } \\
\text { lity period } \\
\text { cant levels a }\end{array}$ & $\begin{array}{l}\text { on-compliant to } \\
\text { ompliant to sha } \\
5 \% \text {, and } 1 \% \text { r }\end{array}$ & $\begin{array}{l}\text { ariah-compli } \\
\text { non-compli } \\
\text { ectively. }\end{array}$ & status & \\
\hline
\end{tabular}

Source: Authors

The results of the paired t-test is shown in Table 10. The results show that Sample-A registered significant difference in dividend size for all market conditions at $0.5411,0.4975$ and 0.5948 at $1 \%$ to $5 \%$ significant levels indicating the superiority of dividend size in the years after the firms are accorded the shariah-compliant status. Interestingly, the paired t-test results on dividend size for Sample-B do not suggest any difference in means of the dividend size between the shariah-compliant years and the shariah non-compliant years suggesting firms 
loosing shariah-compliant status still pay the same size of dividends similar to during their shariah-compliant years.

The above results thus indicate that the firms on Sample-A pay bigger dividends after they are accorded shariah-compliant status while the firms on Sample-B maintain consistent dividend size even after they are revoked of shariah-compliant status.

\section{Discussions}

The findings above, to a certain degree, is consistent with the findings by previous studies (Guizani, 2017; Rahman \& Wajdi, 2006; Hassan, 2003) which showed that shariah-compliant firms have more propensities to pay dividend than shariah non-compliant firms. However, while previous researchers are on general comparison between shariah-compliant and shariah Non-compliant firms, this analysis narrowed down to the pre- and post-shariah-compliant status changes thus exposing the impact of shariah-compliant certification as well as its cancellation to the firms. In this study, it is found that, while shariah-compliant certification has positives impacts on firms' dividend payout decisions, its' cancellation, startlingly, does not necessarily overturn the long-held dividend policies of the firms. The firms, even after losing the shariah-compliant status, tended to maintain stable dividend policy, perhaps in an effort not to portray negative overtone related to the annulment of the shariah-compliant status to the stockholders and the market.

The unexpected dividend behavior of firms in Sample-B in the results of the analysis is also interesting and needs explanation. The expectation is that the firms after revocation of shariah-compliant status would change their dividend payout policies from dividend payers to dividend non-payers which is obviously absent in all market conditions. Thus the results could point to the life-cycle characteristics of the two samples rather than the effect of different market conditions. Firms in Sample-A are newly included in the stock market and are at growth stage which characterized by Fama and French (2001) as firms with abundant investment opportunities and thus have less propensity to pay dividends. However, in this study, the firms are influenced by the shariah-compliant status, and thus, tend to pay bigger dividends knowing all too well the tacit expectation under shariah system that prefers dividends over the forbidden short term capital gains or speculations. This scenario is unlikely to happen in firms at maturity stage (in Sample-B) as they seemed to prefer a stable and predictable dividend policy, perhaps, as not to project negative signal to investors. Therefore, the dividend policies of firms in Sample-B show no distinction between shariah-compliant years and the years after they are stripped of shariah-compliant status.

The different behavior of relatively matured firms as in Sample-B also observed in the financial leverage variable represented by debt-to-asset ratio which show negative correlations to dividend payout decisions in all market conditions. This implies that matured firms are more cautious in their debt condition before making any dividend payout decision as compared to relatively new firms as in Sample-A. Another characteristic observed in more matured firms as in Sample-B is the lack of bearing of the different market conditions while analyzing the association the firms' profitability (represented by $R O A$ variable) to the dividend payout decisions. Sample-A, on the other hand, signifies higher association of firms' profitability to the dividend payout decisions during recovery period (Period P-1) as compared to stability period (Period P-2). It shows that the mature firms do not associate profitability with their dividend policy irrespective of the market conditions thus maintaining stable dividend payouts policy throughout the years. 
The recovery and market stability periods also expose the degree of the impacts of the size of the firms on the dividend payout decisions. The firms' size variable, represented by market capitalization, seemed to correlate more on dividend payout decisions during stability period as compared to recovery period in all samples (both Sample-A and Sample-B) which shows bigger firms have more propensities to pay dividends as compared to smaller firms irrespective of life-cycle stage of the firms provided the market condition is stable.

\section{Conclusions}

The shariah-compliant certification applied on firms in Kuala Lumpur Shariah Index (KLSI) positively signals the propensities of the shariah-compliant firms to pay dividends. New firms certified with shariah-compliant status not only have propensities to pay dividend but also registered increase in dividends for periods after certified shariah-compliant status.

Unexpectedly, firms revoked of shariah-compliant status also found to maintain consistent favorable dividend policy during their shariah-compliant years even when they no longer included in the Islamic index, possibly in appeasing their loyal and supportive prudent and dividend types of investors. Another factor is possibly also due to the life-cycle of the firms which are found to be more mature when their shariah-compliant status were annulled.

The findings of this study also indicate that Islamic investors may not necessarily have to pay opportunity costs for adhering to their faith in Islamic investment or the opportunity cost of discipleship as coined by Mueller (1991). Shariah-compliant firms have charted excellence performance both in wealth creation and wealth distribution through dividend payouts even in different market conditions.

As expected, other criteria on the firms' performance are also taken into accounts in the dividend payout decisions such as firms' size, leverage and profitability. Bigger firms have more propensities to pay dividends than smaller firms while mature firms are more cautious of their leverage ratio when making dividend payout decisions. Profitability has more bearing on newer firms in dividend payout decisions as compared to mature firms.

\section{Limitations of the Study}

The area of study on dividend decision is vast and boundless. However, this study focuses only on firms in the Islamic index in Bursa Malaysia. This is, first and foremost, due to the availability of data. It should be cautioned that the results of the study may not representative of situations in other Islamic indices or screens. The study also constrained by the short time horizons, since the inception of Islamic index only takes place in 1999. Longer time horizons would have had provided us with more information on the firms and the index.

\section{References}

Ahmed, T. (2002). Accounting issues for Islamic banks. In: S. Archer \& R.A. Karim (eds.), islamic finance, innovation and growth (pp.109-125). London: Euromoney books and AAOIFI.

Allen, F., Bernardo, A., \& Welch, I. (2000). A theory of dividends based on tax clienteles. The Journal of Finance, 55(6), 2499-2536. 
Barber, B. M. \& Lyon, J. D. (1996). Detecting abnormal operating performance: the empirical power and specification of test statistics. Journal of Financial Economics, 41(3), 359399.

Bichara, Z. (2008). Institutional ownership and dividend policy: a framework based on tax clientele, information signaling and agency costs. Unpublished $\mathrm{PhD}$ dissertation, University of North Texas, Denton, Texas.

DeLorenzo, Y. T. (2000). Shariah supervision of Islamic mutual funds. Proceedings of the 4th Harvard Forum on Islamic Finance, Center for Middle Eastern Studies, Harvard University, Cambridge, MA.

Derigs, U. \& Marzban, S. (2008). Review and analysis of current shariah-compliant equity screening practices. International Journal of Islamic and Middle Eastern Finance and Management, 1(4), 285-303.

El-Gamal, M. A. (2000). An economic explication of the prohibition of Riba in classical Islamic Jurisprudence. Islamic Economic Studies, 8(2), 1-20.

Elgari, M. (2000). Purification of Islamic equity funds: methodology and Shari'ah Foundation. Proceedings of the Fourth Harvard University Forum on Islamic Finance, Harvard University, Cambridge, MA.

Fama, E. F. \& French, K. R. (2001). Disappearing dividends: changing firm characteristics or lower propensity to pay? Journal of Financial Economics, 60(1), 3-43.

Forte, G. \& Miglietta, F. (2007). Islamic mutual funds as faith-based funds in a socially responsible context. Conference Paper. Retrieved from papers.ssrn.com/sol3/papers.cfm? abstract_id=1012813

Guizani, M. (2017). Free cashflow, agency cost and dividend policy of sharia-compliant and non-sharia-compliant firms. International Journal of Economics and Management. 11(2), 355-370.

Hardie, A. \& Rabooy, M. (1991). Risk, piety, and the Islamic investor. British Journal of Middle Eastern Studies, 18(1), 52-66.

Hassan, M. K. (2003). Dividend signaling hypothesis and short-term asset concentration of Islamic interest-free banking. Islamic Economic Studies, 11(1), 1-30.

Iqbal, Z. \& Mirakhor, A. (2012). An introduction to Islamic finance: theory and practice. Singapore: John Wiley and Sons Asia Pte ltd.

Jensen, M. C. (1986). Agency costs of free cashflow, corporate finance, and takeovers. The American Economic Review, 76(2), 323-329.

Kadioglu, E. \& Yilmaz, E.A. (2017). Is the free cash flow hypothesis valid in Turkey? Borsa Istanbul Review, 17(2),111-116.

Kumar, P. K. (1988). Shareholders-manager conflict and the information content of dividends. The Review of Financial Studies, 1(2), 111-136.

Lang, L. H. P. \& Litzenberger, R. H. (1989). Dividend announcements: cashflow signalling vs. free cashflow hypothesis. Journal of Financial Economics, 24(1), 181-191.

Lintner, J. (1962). Dividends, earnings, leverage, stock prices and supply of capital to corporations. The Review of Economics and Statistics, 44(3), 243-269.

Mansor, F. (2006). Wealth creation and wealth generation: analysis from Qur`anic perspective. Paper presented at National Seminar in Islamic Banking \& Finance, August 29-30, Kuala Lumpur, Malaysia. Unpublished. Retrieved from: http://eprints.um.edu.my /927/

McNemar, Q. (1947). Note on the sampling error of the difference between correlated proportions or percentages. Psychometrika, 12(2), 153-157. 
Mueller, D. C. (1972). A life cycle theory of the firm. Journal of Industrial Economics, 20(3), 199-219.

Mueller, S. (1991). The opportunity cost of discipleship: ethical mutual funds and their returns. Sociological Analysis, 52(1), 111-124.

Naughton, S. \& Naughton, T. (2000). Religion, ethics and stock trading: the case of an Islamic equities market. Journal of Business Ethics, 23(2),145-159.

Rahman, A. F. \& Wajdi, M. F. (2006). Dividend signaling hypothesis and agency cost: an investigation on Shariah and Non-Shariah compliant firms in Kuala Lumpur Shariah index. Empirika, 19 (1), 1-9.

Shariah Advisory Council. (2006). Resolutions of the securities commission shariah advisory council $\left(2^{\text {nd }}\right.$ e.d.). Kuala Lumpur: Securities Commission.

Vogel, F. \& Hayes, S. (2006). Islamic law and finance: religion, risk, and return. Leiden: Brill.

Wald, J. K. (1999). How firm characteristics affect capital structure: an international comparison. The Journal of Financial Research, 22(2), 161-187.

Warde, I. (2000). Islamic finance in the global economy. Edinburgh: Edinburgh University Press. 